\title{
Bioactive Phenolics and Polyphenols: Current Advances and Future Trends
}

\author{
Daniel A. Jacobo-Velázquez ${ }^{1, *(1)}$ and Luis Cisneros-Zevallos ${ }^{2, *(1)}$ \\ 1 Tecnologico de Monterrey, Escuela de Ingeniería y Ciencias, Ave. Eugenio Garza Sada 2501, \\ Monterrey NL C.P. 64849, Mexico \\ 2 Department of Horticultural Sciences, Texas A\&M University, College Station, TX 77843-2133, USA \\ * Correspondence: djacobov@itesm.mx (D.A.J.-V.); lcisnero@tamu.edu (L.C.-Z.); \\ Tel.: +52-818-358-2000 (ext. 4821) (D.A.J.-V.); +1-979-845-3244 (L.C.-Z.)
}

Received: 23 August 2020; Accepted: 25 August 2020; Published: 26 August 2020

Phenolic compounds are secondary plant metabolites with remarkable health-promoting properties. More than 8000 phenolics have been identified from natural sources [1]. In plants, phenolics play different physiological roles, such as plant growth regulators and as important chemical precursors for the biosynthesis of other molecules such as lignin and suberin, which are produced as a defense mechanism against different biotic and abiotic stresses [2].

Twenty-six contributions (19 research and seven review articles) in this Special Issue show some of the current advances in bioactive phenolics and polyphenols. Research articles published were mainly focused on the evaluation of different bioactivities of phenolics, with an emphasis on the prevention of chronic diseases, whereas another important number of papers described methods for the production of phenolics by chemoenzymatic preparations [3], hairy root culture bioreactors [4], and elicitation of the secondary plant metabolism by preharvest [5] and postharvest [6] abiotic stresses.

Regarding research published on the effect of phenolics to prevent chronic diseases, it was reported that ellagic acid (a component of ellagitannins, present in crops such as pecans, walnuts, and berries) and its metabolites urolithins A and B, produced by the gut microbiota, differentially regulate fat accumulation and inflammation in 3T3-L1 adipocytes, while not affecting adipogenesis and insulin sensitivity [7]. Another report evaluating the microbial metabolites of chlorogenic acid demonstrated their anti-proliferative effects, S-phase cell-cycle arrest, and apoptosis in human colon cancer Caco-2 cell [8]. Furthermore, carnosol was identified as a component of rosemary extract with potential application as glucose regulating agent by increasing muscle cell glucose uptake via AMPK-dependent GLUT4 glucose transporter translocation [9]. Likewise, the anti-hypertensive effects of polyphenols from acacia (an evergreen tree belonging to the genus Acacia in the legume family) was reported, using spontaneously hypertensive rats as an experimental model [10]. Other published papers in this Special Issue showed the in vivo attenuation effect of ischemic myocardial damage by phenolic extracts from Crataegus oxyacanth and Rosmarinus officinalis [11], whereas it was reported that extracts from Aspidosperma pyrifolium presented in vivo anti-inflammatory properties in mice with peritonitis [12].

Furthermore, other contributors to this Special Issue reported the potential use of 3,5,6,7,8,3' ${ }^{\prime}{ }^{\prime}$ heptamethoxyflavone, a Citrus flavonoid, for the preparation of skincare products due to its capacity to inhibit collagenase activity and to induce type-I procollagen synthesis in UV-induced human dermal fibroblast neonatal (HDFn) cells [13]. Other bioactive properties of phenolics reported were the inhibition of Zika virus infection by isoquercitin [14], the neuroprotective effects of anthocyanin-enriched extracts from berries [15] and quercetin [16], and the antibacterial effects against Staphylococcus aureus of flavonoids from the traditional Japanese medicine keigairengyoto [17]. Isorhamnetin and quercetin derivatives were reported as the anti-acetylcholinesterase principles of marigold (Calendula officinalis) flowers and preparations [18], whereas the antinociceptive effect of Arrabidaea brachypoda (DC) bureau 
phenolic extract was also demonstrated [19]. The intestinal permeability, cellular antioxidant activity, and plasma stability of phenolic compounds from mango [20] and isorhamnetin glycoside from Opuntia ficus-indica (L.) [21] were also reported in the Special Issue.

The Special Issue included seven review papers that describe the current status of phenolic compounds, covering general aspects of their bioactivity for the suppression of chronic diseases [1], as well as the bioactivity of specific group of phenolics such as the stilbenoids [22,23], ellagitannins, and anthocyanins [24]. In addition, the health-promoting properties of phenolics present in lentils [25] and dry common beans [26] were also reviewed. Finally, a review article describing nanofiltration and tight ultrafiltration membrane techniques for the recovery of polyphenols from agro-food by-products was also presented [27].

The evaluation of phenolics bioactivities from different plant sources is a growing area of research. Every year, new scientific information supports the increased potential of phenolics to prevent different chronic and degenerative diseases. Further research should continue the direction of identifying natural sources rich in phenolics and evaluating their bioactivities. However, now that the bioactivity of phenolics from several plant materials has been characterized, further research efforts could be focused on taking the generated fundamental science into the market through developing innovative food products and dietary supplement formulations. One interesting emerging area of research is the design of effective nutraceutical combinations in the form of foods, beverages, and dietary supplements that could be used not only in the prevention of chronic disease but also for their treatment [28]. In this context, the synergistic combination of phenolic compounds with other nutraceuticals should be evaluated for the prevention and treatment of chronic diseases [29]. Furthermore, the development of bioprocesses to obtain next-generation functional food and beverages is crucial to reach the market and provide the desired beneficial effect of phenolic compounds to the population. In this context, it has been recently proposed that the application of postharvest abiotic stresses in horticultural crops to increase the content of phenolic compounds, and their further transformation into processed food products using nonthermal processing technologies, could be an effective approach to obtain shelf-stable products with a high content of antioxidant phenolic compounds [30].

Acknowledgments: The Guest Editors would like to thank all authors for their contributions to this Special Issue, as well as the reviewers and editorial staff of International Journal of Molecular Sciences for their meticulous work on the evaluation of the submitted articles.

Conflicts of Interest: The authors declare no conflict of interest.

\section{References}

1. Shahidi, F.; Yeo, J. Bioactivities of phenolics by focusing on suppression of chronic diseases: A review. Int. J. Mol. Sci. 2018, 19, 1573. [CrossRef] [PubMed]

2. Torres-Contreras, A.M.; Nair, V.; Cisneros-Zevallos, L.; Jacobo-Velázquez, D.A. Effect of exogenous amylolytic enzymes on the accumulation of chlorogenic acid isomers in wounded potato tubers. J. Agric. Food. Chem. 2014, 62, 7671-7675. [CrossRef] [PubMed]

3. Valentová, K.; Káňová, K.; Di Meo, F.; Pelantová, H.; Chambers, C.S.; Rydlová, L.; Petrásková, L.; Křenková, A.; Cvačka, J.; Trouillas, P.; et al. Chemoenzymatic preparation and biophysical properties of sulfated quercetin metabolites. Int. J. Mol. Sci. 2017, 18, 2231. [CrossRef] [PubMed]

4. Renouard, S.; Corbin, C.; Drouet, S.; Medvedec, B.; Doussot, J.; Colas, C.; Maunit, B.; Bhambra, A.S.; Gontier, E.; Jullian, N.; et al. Investigation of Linum flavum (L.) hairy root cultures for the production of anticancer aryltetralin lignans. Int. J. Mol. Sci. 2018, 19, 990. [CrossRef]

5. Moreira-Rodríguez, M.; Nair, V.; Benavides, J.; Cisneros-Zevallos, L.; Jacobo-Velázquez, D.A. UVA, UVB Light, and methyl jasmonate, alone or combined, redirect the biosynthesis of glucosinolates, phenolics, carotenoids, and chlorophylls in broccoli sprouts. Int. J. Mol. Sci. 2017, 18, 2330. [CrossRef] [PubMed]

6. Ortega-Hernández, E.; Nair, V.; Welti-Chanes, J.; Cisneros-Zevallos, L.; Jacobo-Velázquez, D.A. Wounding and UVB light synergistically induce the biosynthesis of phenolic compounds and ascorbic acid in red prickly pears (Opuntia ficus-indica cv. Rojo Vigor). Int. J. Mol. Sci. 2019, 20, 5327. [CrossRef] 
7. Cisneros-Zevallos, L.; Bang, W.Y.; Delgadillo-Puga, C. Ellagic acid and urolithins A and B differentially regulate fat accumulation and inflammation in 3T3-L1 adipocytes while not affecting adipogenesis and insulin sensitivity. Int. J. Mol. Sci. 2020, 21, 2086. [CrossRef]

8. Sadeghi Ekbatan, S.; Li, X.-Q.; Ghorbani, M.; Azadi, B.; Kubow, S. Chlorogenic acid and its microbial metabolites exert anti-proliferative effects, S-phase cell-cycle arrest and apoptosis in human colon cancer Caco-2 cells. Int. J. Mol. Sci. 2018, 19, 723. [CrossRef]

9. Vlavcheski, F.; Baron, D.; Vlachogiannis, I.A.; MacPherson, R.E.K.; Tsiani, E. Carnosol increases skeletal muscle cell glucose uptake via AMPK-dependent GLUT4 glucose transporter translocation. Int. J. Mol. Sci. 2018, 19, 1321. [CrossRef]

10. Ikarashi, N.; Toda, T.; Hatakeyama, Y.; Kusunoki, Y.; Kon, R.; Mizukami, N.; Kaneko, M.; Ogawa, S.; Sugiyama, K. Anti-hypertensive effects of acacia polyphenol in spontaneously hypertensive rats. Int. J. Mol. Sci. 2018, 19, 700. [CrossRef]

11. Cuevas-Durán, R.E.; Medrano-Rodríguez, J.C.; Sánchez-Aguilar, M.; Soria-Castro, E.; Rubio-Ruíz, M.E.; Del Valle-Mondragón, L.; Sánchez-Mendoza, A.; Torres-Narvaéz, J.C.; Pastelín-Hernández, G.; Ibarra-Lara, L. Extracts of Crataegus oxyacantha and Rosmarinus officinalis attenuate ischemic myocardial damage by decreasing oxidative stress and regulating the production of cardiac vasoactive agents. Int. J. Mol. Sci. 2017, 18, 2412. [CrossRef]

12. Souza Lima, M.C.J.; Oliveira Bitencourt, M.A.; Furtado, A.A.; Torres-Rêgo, M.; Siqueira, E.M.S.; Oliveira, R.M.; Oliveira Rocha, H.A.; Ferreira Rocha, K.B.; Silva-Júnior, A.A.; Zucolotto, S.M.; et al. Aspidosperma pyrifolium has anti-inflammatory properties: An experimental study in mice with peritonitis Induced by Tityus serrulatus venom or carrageenan. Int. J. Mol. Sci. 2017, 18, 2248. [CrossRef] [PubMed]

13. Kim, H.-I.; Jeong, Y.-U.; Kim, J.-H.; Park, Y.-J. 3,5,6,7,8,3' '4'-Heptamethoxyflavone, a Citrus flavonoid, inhibits collagenase activity and induces type I procollagen synthesis in HDFn cells. Int. J. Mol. Sci. 2018, 19, 620. [CrossRef] [PubMed]

14. Gaudry, A.; Bos, S.; Viranaicken, W.; Roche, M.; Krejbich-Trotot, P.; Gadea, G.; Desprès, P.; El-Kalamouni, C. The flavonoid isoquercitrin precludes initiation of Zika virus infection in human cells. Int. J. Mol. Sci. 2018, 19, 1093. [CrossRef] [PubMed]

15. Ma, H.; Johnson, S.L.; Liu, W.; DaSilva, N.A.; Meschwitz, S.; Dain, J.A.; Seeram, N.P. Evaluation of polyphenol anthocyanin-enriched extracts of blackberry, black raspberry, blueberry, cranberry, red raspberry, and strawberry for free radical scavenging, reactive carbonyl species trapping, anti-glycation, anti- $\beta$-amyloid aggregation, and microglial neuroprotective effects. Int. J. Mol. Sci. 2018, 19, 461.

16. Bahar, E.; Kim, J.-Y.; Yoon, H. Quercetin attenuates manganese-induced neuroinflammation by alleviating oxidative stress through regulation of apoptosis, iNOS/NF-kB and HO-1/Nrf2 pathways. Int. J. Mol. Sci. 2017, 18, 1989. [CrossRef]

17. Matsumoto, T.; Kaneko, A.; Koseki, J.; Matsubara, Y.; Aiba, S.; Yamasaki, K. Pharmacokinetic study of bioactive flavonoids in the traditional japanese medicine keigairengyoto exerting antibacterial effects against Staphylococcus aureus. Int. J. Mol. Sci. 2018, 19, 328. [CrossRef]

18. Olennikov, D.N.; Kashchenko, N.I.; Chirikova, N.K.; Akobirshoeva, A.; Zilfikarov, I.N.; Vennos, C. Isorhamnetin and quercetin derivatives as anti-acetylcholinesterase principles of marigold (Calendula officinalis) flowers and preparations. Int. J. Mol. Sci. 2017, 18, 1685. [CrossRef]

19. Rodrigues, V.P.; Rocha, C.Q.; Périco, L.L.; Santos, R.D.C.; Ohara, R.; Nishijima, C.M.; Ferreira Queiroz, E.; Wolfender, J.-L.; Rocha, L.R.M.; Santos, A.R.S.; et al. Involvement of opioid system, TRPM8, and ASIC receptors in antinociceptive effect of Arrabidaea brachypoda (DC) bureau. Int. J. Mol. Sci. 2017, 18, 2304. [CrossRef]

20. Pacheco-Ordaz, R.; Antunes-Ricardo, M.; Gutiérrez-Uribe, J.A.; González-Aguilar, G.A. Intestinal permeability and cellular antioxidant activity of phenolic compounds from mango (Mangifera indica $\mathrm{cv}$. Ataulfo) peels. Int. J. Mol. Sci. 2018, 19, 514. [CrossRef]

21. Antunes-Ricardo, M.; Rodríguez-Rodríguez, C.; Gutiérrez-Uribe, J.A.; Cepeda-Cañedo, E.; Serna-Saldívar, S.O. Bioaccessibility, Intestinal permeability and plasma stability of isorhamnetin glycosides from Opuntia ficus-indica (L.). Int. J. Mol. Sci. 2017, 18, 1816. [CrossRef] [PubMed]

22. Akinwumi, B.C.; Bordun, K.-A.M.; Anderson, H.D. Biological activities of stilbenoids. Int. J. Mol. Sci. 2018, 19, 792. [CrossRef] [PubMed] 
23. Farooqi, A.A.; Khalid, S.; Ahmad, A. Regulation of cell signaling pathways and miRNAs by resveratrol in different cancers. Int. J. Mol. Sci. 2018, 19, 652. [CrossRef]

24. García-Conesa, M.-T.; Chambers, K.; Combet, E.; Pinto, P.; Garcia-Aloy, M.; Andrés-Lacueva, C.; De Pascual-Teresa, S.; Mena, P.; Konic Ristic, A.; Hollands, W.J.; et al. Meta-analysis of the effects of foods and derived products containing ellagitannins and anthocyanins on cardiometabolic biomarkers: Analysis of factors influencing variability of the individual responses. Int. J. Mol. Sci. 2018, 19, 694. [CrossRef] [PubMed]

25. Ganesan, K.; Xu, B. Polyphenol-rich lentils and their health promoting effects. Int. J. Mol. Sci. 2017, 18, 2390. [CrossRef]

26. Ganesan, K.; Xu, B. Polyphenol-rich dry common beans (Phaseolus vulgaris L.) and their health benefits. Int. J. Mol. Sci. 2017, 18, 2331. [CrossRef]

27. Cassano, A.; Conidi, C.; Ruby-Figueroa, R.; Castro-Muñoz, R. Nanofiltration and tight ultrafiltration membranes for the recovery of polyphenols from agro-food by-products. Int. J. Mol. Sci. 2018, 19, 351. [CrossRef]

28. Santana-Gálvez, J.; Cisneros-Zevallos, L.; Jacobo-Velázquez, D.A. A practical guide for designing effective nutraceutical combinations in the form of foods, beverages, and dietary supplements against chronic degenerative diseases. Trends Food Sci. Technol. 2019, 88, 179-193. [CrossRef]

29. Santana-Gálvez, J.; Villela-Castrejón, J.; Serna-Saldívar, S.O.; Cisneros-Zevallos, L.; Jacobo-Velázquez, D.A. Synergistic combinations of curcumin, sulforaphane, and dihydrocaffeic acid against human colon cancer cells. Int. J. Mol. Sci. 2020, 21, 3108. [CrossRef]

30. Jacobo-Velázquez, D.A.; Santana-Gálvez, J.; Cisneros-Zevallos, L. Designing next-generation functional food and beverages: Combining nonthermal processing technologies and postharvest abiotic stresses. Food Eng. Rev. 2020. [CrossRef]

(C) 2020 by the authors. Licensee MDPI, Basel, Switzerland. This article is an open access article distributed under the terms and conditions of the Creative Commons Attribution (CC BY) license (http://creativecommons.org/licenses/by/4.0/). 